\title{
APPLICATION OF MODERN PRE-TREATMENTS IN PLUM DRYING
} UPOTREBA MODERNIH PREDTRETMANA PRILIKOM SUŠENJA ŠLJIVE

\author{
Tvrtko JELAČIĆ ${ }^{*}$, Sandra VOĆA ${ }^{* *}$, Verica DRAGOVIĆ UZELAC $C^{* * *}$, Ante GALIĆ ${ }^{* *}$, Jana ŠIC ŽLABUR ${ }^{* *}$ \\ ${ }^{*}$ Croatian Agency for Agriculture and Food, I.Gundulića 36, 31000 Osijek \\ ${ }^{* *}$ University of Zagreb Faculty of Agriculture, Svetošimunska cesta 25, 10000 Zagreb, Croatia \\ ${ }^{* * *}$ University of Zagreb Faculty of Food Technology and Biotechnology, Pierottijeva 6, 10000 Zagreb, Croatia \\ e-mail:svoca@agr.hr
}

\begin{abstract}
The purpose of this study is to determine the influence of abrasive pre-treatments on plum drying time compared to the conventional ones. The mechanical pre-treatment examined included the abrasion at three different cylinder rotation times: 5,10 and $15 \mathrm{~min}$. The chemical pre-treatment under consideration included the immersion of plums in alkaline solution (KOH) of different concentrations $(0.5,1$ and $1.5 \%(\mathrm{v} / \mathrm{v}))$ at $60^{\circ} \mathrm{C}$ for one minute. The thermal treatment performed included the immersion of fruits in distilled water at $60^{\circ} \mathrm{C}$ for one minute. As a control (untreated) sample, fruits with waxy lawyers were used. According to the results obtained, the drying time of plums was significantly reduced compared to the control sample (97 h): in the samples treated with distilled water (thermal treatment) drying time was reduced by $21 \mathrm{~h}$, whereas the drying time reduction of up to $68 \mathrm{~h}$ was reorded using a $\mathrm{KOH}$ solution of $1.5 \%$. In the samples pre-treated by abrasion for $15 \mathrm{~min}$, the drying time recorded was also reduced by 68 $h$ compared to the control samples, thus proving the exceptional efficiency of abrasive pre-treatment in plum drying.
\end{abstract}

Key words: abrasion, chemical pre-treatment, drying time, convection, plum.

\section{REZIME}

Novija istraživanja sušenja šljiva podrazumijevaju temperature niže od $50^{\circ} \mathrm{C}$, s udjelom vode u plodu oko 35\%. Proces sušenja šljiva je spor i energetski zahtjevan zbog specifičnog voštanog sloja kojim je prekrivena kožica ploda. Kako bi se uklonila voštana prevlaka $i$ omogućilo slobodno kretanje vode potrebno je prije procesa sušenja primijeniti predtretmane kojim se omogućuje razgradnja voštane prevlake, a time i stvaraju mikroskopske pukotine koje povećavaju propusnost vode. Potražnja tržišta za ekološki prihvatljivijim proizvodima dovela je do razvoja abrazivnih predtretmana koji za uklanjanje voštane prevlake koriste razne inertne materijale. Cilj ovog rada bio je istražiti utjecaj primjene abrazivnog predtratmana na vrijeme sušenja u odnosu na konvencionalne predtretmane. Mehanički predtretman uključivao je upotrebu abrazije pri tri različita vremena vrtnje cilindra: $5,10 i 15$ minuta. Kemijski predtretman uključivao je potapanje plodova u otopinu lužine (KOH) različitih koncentracija 0,5, 1 i 1,5\% (v/v) pri temperaturi $60^{\circ} \mathrm{C} i$ trajanju od jedne minute. Toplinski predtretman uključivao je potapanje plodova u destiliranu vodu temperature $60^{\circ} \mathrm{C}$ u trajanju od jedne minute. Kao kontrolni uzorak korišteni su plodovi koji nisu predtretirani, odnosno nije im uklonjena voštana prevlaka. Prema dobivenim rezultatima vrijeme sušenja se značajno skratilo u odnosu na kontrolni uzorak (97 h) $i$ to kod tretmana destiliranom vodom za 21 sat, a upotrebom otopine KOH 1,5\% za čak 68 sati. Kod uzoraka tretiranih abrazijom uz vrijeme vrtnje od 15 min vrijeme sušenja se također skratilo za 68 sati čime se može potvrditi iznimna učinkovitost abrazivnog predtretmana u procesu sušenja ploda šljive.

Key words: abrazija, hemijski predtretmani, vreme sušenja, konvencionalno, šljiva.

\section{INTRODUCTION}

Owing to a high water content, fresh plum fruits are vulnerable to spoilage and thus often processed into different products. One of the most important plum products are prunes obtained by different drying methods. The technology of prune production is mainly based on drying at high temperatures (between 85 and $90^{\circ} \mathrm{C}$ ), with lower fruit water contents (between 20 and 26 \%) (Okos et al., 1992; Cvejanov et al., 2004). Drying period significantly depends on the type and preparation methods of raw materials, as well as the use of pre-treatment (Okos et al., 1992; Cvejanov et al., 2004; Grabowski, 2005; Mitić at al., 2015). The dehydration of fruit at high temperatures can adversely affect the fruit quality on account of the texture, color, flavor, nutrient and bioactive compound losses, which require high energy consumption. Recent studies on fruit drying have included temperatures lower than $50^{\circ} \mathrm{C}$ with a higher final fruit water content of about $35 \%$ and longer time period (UN, 2003; Tarhan, 2007; Adiletta et al., 2015). Abrasive drying method has a positive effect on the texture, color, taste and nutritional value of fruit, featuring relatively low energy with a longer drying period of 50 to 72 h (Cinquanta et al., 2002; Doymaz and Pala 2002; Adiletta et al., 2014). Drying process of plums is slow and energy-demanding due to a specific waxy layer that covers the fruit skin. In order to remove the waxy coating and allow the free movement of water from fruit, it is necessary to apply pre-treatments which decompose the waxy layer and create microscopic cracks increasing the water permeability. The drying of pre-treated fruits is significantly faster compared to untreated ones (Cinqvanta et al., 2002; Doymaz and Pala 2002; Gazor et al., 2014; Bursać et al., 2014). The most common pre-treatments used in the technology of prune production are based on different thermal and chemical treatments. However, the growing demand of market and consumers for more environmentally friendly products has led to the development of abrasive pre-treatments which use various inert materials to remove wax coating from the fruit skin (Di Matteo et al., 2000; Di Matteo et al., 2002; Cinquanta et al., 2002; Adiletta et al., 2014; Adiletta et al., 2016). Therefore, the objective of this study was to determine the influence of abrasive pre-treatment on the plum drying time compared to the conventional pre-treatments.

\section{MATERIALS AND METHODS}

For the research purposes, plum fruits of the cv. 'Bistrica' were used, obtained from the experimental orchard in Donja Zelina. Fruits were collected in the optimum harvest period, when the dry soluble solids and total acids ratio were optimal for the cultivar selected. The fruits were collected manually in plastic containers at early morning hours and dry weather. After harvest, fruits were transported to the laboratory of the Croatian Agency for Food and Agriculture for analysis. Fruits intended 
for drying were sorted according to the size, previously removing all fruits with mechanical damage. Before drying, fruits were washed and pitted mechanically. For the purpose of waxy layer removal from the fruit skin, different pre-treatments were used: mechanical, chemical and hot water treatments (thermal). The mechanical pre-treatment performed included the abrasion using a cylinder coated on the inside with the inert abrasive material type PW400. The cylinder rotation speed was $120 \mathrm{rpm}$, and the abrasive pre-treatment was performed at three different cylinder rotation times: 5, 10 and 15 min. The chemical pre-treatment performed included the immersion of fruits in alkaline solution $(\mathrm{KOH})$ of different concentrations $(0.5,1$ and $1.5 \%(\mathrm{v} / \mathrm{v}))$ at a temperature of $60{ }^{\circ} \mathrm{C}$ for one minute. After the chemical pre-treatment, fruits intended for drying were washed several times with distilled water in order to remove the excess alkaline. The thermal treatment performed included the immersion of fruits in distilled water at a temperature of $60^{\circ} \mathrm{C}$ for one minute. Table 1 shows the experiment design of plum fruit pre-treatments. Control samples were fruits which were not pre-treated, i.e. featuring a waxy layer.

Table 1. Design of the plum pre-treatment experiment

\begin{tabular}{|c|c|c|c|c|c|}
\hline Treatment & Sample & $\begin{array}{c}\text { Time } \\
(\mathrm{min})\end{array}$ & Solvent & $\begin{array}{c}\text { Con. } \\
(\% \mathrm{v} / \mathrm{v})\end{array}$ & $\begin{array}{c}\text { Temperature } \\
\left({ }^{\circ} \mathrm{C}\right)\end{array}$ \\
\hline Control & $\mathrm{C}$ & - & - & - & - \\
\hline \multirow{4}{*}{ Abrasia } & $\mathrm{A} 1$ & 5 & - & - & - \\
\cline { 2 - 6 } & $\mathrm{A} \mathrm{2}$ & 10 & - & - & - \\
\cline { 2 - 6 } & $\mathrm{A} \mathrm{3}$ & 15 & - & - & - \\
\hline \multirow{3}{*}{ Chemical } & $\mathrm{K} 1$ & 1 & $\mathrm{KOH}$ & 0.5 & 60 \\
\cline { 2 - 6 } & $\mathrm{K} 2$ & 1 & $\mathrm{KOH}$ & 1.0 & 60 \\
\cline { 2 - 6 } & $\mathrm{K} 3$ & 1 & $\mathrm{KOH}$ & 1.5 & 60 \\
\hline Thermal & $\mathrm{D}$ & 1 & $\mathrm{H}_{2} \mathrm{O}$ & - & 60 \\
\hline
\end{tabular}

Before drying, the total moisture content of all plum fruits was determined using the standard method (AOAC, 1995). After pre-treatment, fruits were properly arranged in the primary layer on the drying shelf. The drying process was conducted by convection in a chamber drier at an air flow rate of $2.0 \mathrm{~m} \mathrm{~s}^{-1}$ and at a constant temperature of $42{ }^{\circ} \mathrm{C}$. The drying process was conducted in triplicate: each replication involved one shelf used for drying $2.2 \mathrm{~kg}$ of fruits. Such prepared fruits were dried until a constant moisture content of $35 \%$. During the entire drying process, the fruit mass was determined every four hours and the moisture content was calculated according to Equation 1.

$$
W 2=100-\frac{m_{1}}{m_{2}} \times(100-W 1)
$$

where W2 is the fruit moisture content (\%) during drying; $\mathrm{W} 1$ is the initial fruit moisture content (\%) before drying; $\mathrm{m} 1$ is the mass sample (g) before drying; and $\mathrm{m} 2$ is the mass sample (g) during drying. In order to determine the final mass to which the fruits should be dried to achieve a water content of $35 \%$, the calculation according to Equation 2 was used.

$$
m_{2}=\frac{m_{1} \times(100-W 1)}{100-W 2}
$$

\section{RESULTS AND DISCUSSION}

The moisture content loss during plum fruit drying is shown in Graphs 1 and 2. According to the results obtained, the longest drying time $(97 \mathrm{~h})$ was recorded in samples in which waxy layer was not removed (C, Graph 1), proving the waxy layer removal necessary before plum drying. Other research also confirms that pre-treatments use significantly shortened drying times (Cinquanta et al., 2002, Di Mateo et al, 2002, Tarhan, 2007, Jazini and Hatamipour, 2010, Gazor et al., 2014). In this study, the use of pre-treatment also significantly shortened the drying period of plums: $21 \mathrm{~h}$ shorter in the instance of the sample $\mathrm{D}, 68$ $\mathrm{h}$ shorter in the instance of the sample A3, and even $69 \mathrm{~h}$ in the instance of the sample K3 (all compared to the control sample (C)). Accordingly, pre-treatments, regardless of the type (thermal, mechanical or chemical), are required in order to reduce the drying time of plums. The use of chemical pretreatments with alkaline solution $(\mathrm{KOH})$, regardless of the concentration $(0.5,1$ and $1.5 \% \mathrm{v} / \mathrm{v})$, greatly reduced the drying time, even 2.5 times compared to the thermal treatment with distilled water (D). The loss of moisture content (\%) from plums pre-treated by alkaline solution, regardless of the concentration (K1, K2, K3), was uniform during the whole drying period (Graph 1). The results of chemical pre-treatment effects on drying time obtained in this research are in accordance with other literature data (Gazor et al., 2014). Tarhan (2007) used different chemical pre-treatments (4\% ethyl oleate (v/v), $1 \%$ $\mathrm{KOH}(\mathrm{v} / \mathrm{v})$ and $1 \% \mathrm{NaOH}(\mathrm{v} / \mathrm{v})$ at two different temperatures (23 and $60{ }^{\circ} \mathrm{C}$ ) and thermal pre-treatments which included the immersion of plums in distilled water at two different temperatures: 23 and $60^{\circ} \mathrm{C}$ ) and compared their effect on drying time. According to the results obtained, the author concluded that the treatment with $\mathrm{KOH}$ and $\mathrm{NaOH}(1 \% \mathrm{v} / \mathrm{v})$ at $60{ }^{\circ} \mathrm{C}$ was the most efficient in shortening the time during plum drying compared to the other varied pre-treatments, even when the lowest drying temperatures $\left(<55^{\circ} \mathrm{C}\right)$ were used. During the use of mechanical pre-treatment by abrasion, the duration of abrasion application significantly influenced the drying time. The shortest drying time was determined in the sample treated by abrasion for $15 \mathrm{~min} \mathrm{A3} \mathrm{(29} \mathrm{h),} \mathrm{which} \mathrm{is} \mathrm{compared} \mathrm{to} \mathrm{the}$ abrasion application of 5 min A1 (42 h) and 10 min A2 (36 h) leading to $45 \%$ and $24 \%$ shorter drying time, respectively. Plum samples pre-treated by abrasion showed differences in the loss of water content (\%) during drying: the most rapid water content loss was obtained in the samples pre-treated by abrasion for $15 \mathrm{~min}$ (A3). Comparing the effect of chemical and mechanical pre-treatment in plum drying, it can be concluded that the same period of $29 \mathrm{~h}$ was needed for plum drying to the intended final fruit moisture content of $35 \%$. Similar results were obtained by Jazini and Hatamipour (2010), who studied the effects of mechanical pre-treatment by needle piercing of skin fruit and chemical pre-treatment by fruit immersion in $\mathrm{NaOH}(1 \% \mathrm{v} / \mathrm{v})$ at $100{ }^{\circ} \mathrm{C}$ on the drying time of plums. The authors concluded that mechanical treatment was more efficient in shortening the drying time of plums compared to the chemical pre-treatment. Cinquanta et al. (2002) compared the efficiency of mechanical pre-treatment by abrasion for $15 \mathrm{~min}$ and chemical by ethyl oleate $(2 \% \mathrm{v} / \mathrm{v})$ and $\mathrm{K}_{2} \mathrm{CO}_{3}(2.5 \% \mathrm{v} / \mathrm{v})$ at 60 ${ }^{\circ} \mathrm{C}$ and also concluded that abrasion pre-treatment significantly shortened drying time compared to the varied chemical pretreatments. In order to determine the loss of water content during plum drying and to obtain drying curves, the derivation of the second-degree polynomial equations (Graphs 1 and 2) was calculated (Table 2). Accordingly, linear equations were obtained, on the basis of which curve slope coefficients were compared (Table 2). The slope coefficients significantly differ depending on the pre-treatment used. The highest slope coefficient (0.0042) was determined in the sample pre-treated by abrasion for 15 min (A3), followed by the samples A1 and A2. In the samples chemically pre-treated (K1, K2 and $\mathrm{K} 3$ ), the highest slope coefficient (0.0024) was determined in the sample pre-treated with $\mathrm{KOH}$ solution of $1.5 \%$ concentration, followed by the sample treated with 0.5 (K1) and $1 \%(\mathrm{~K} 2) \mathrm{KOH}$ solution. In the thermally pre-treated sample (D), a slope coefficient of 0.0006 was determined. The control sample (C) had the lowest slope coefficient (0.0004), suggesting that the water content loss in this sample was the lowest. According to the obtained slope coefficients, it can be concluded that the pre-treatment type strongly affects the water loss content and is required as one of the major steps in the technology of plum drying. 


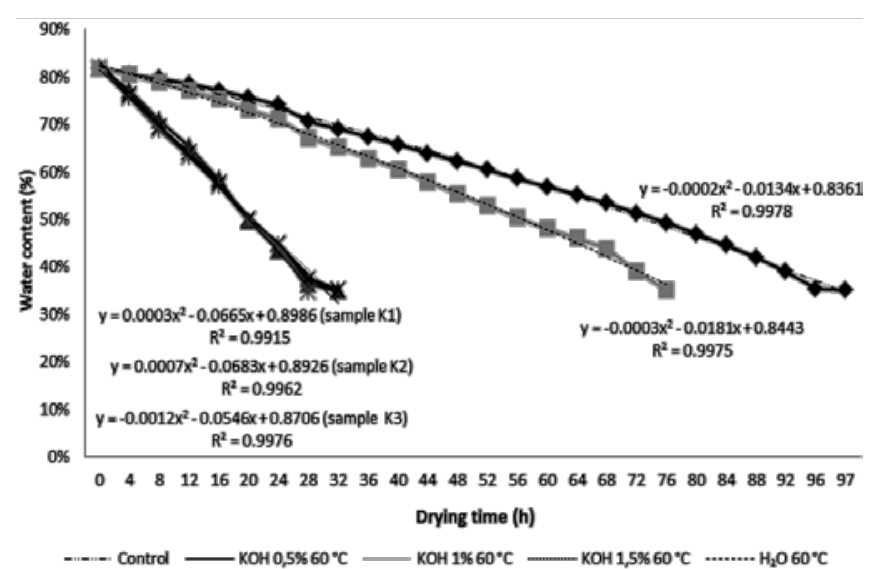

Fig. 1. Loss of water content (\%) during the drying of untreated plum fruits (control), fruits treated with $\mathrm{KOH}$ and $\mathrm{H}_{2} \mathrm{O}$

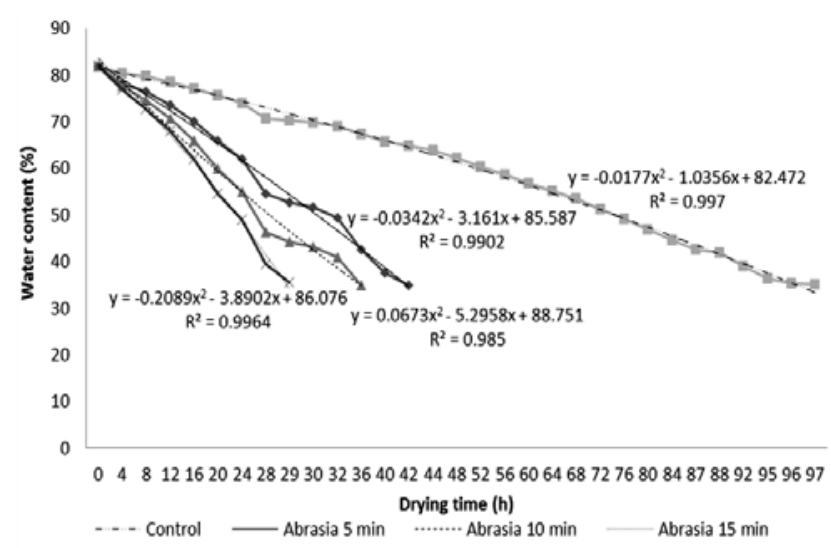

Fig. 2. Loss of water content (\%) during the drying of untreated plums (control) and abrasion-treated fruits

Table 2. Derivation of the second-degree polynomial equations for drying curves and final drying time of each sample \begin{tabular}{|l|l|l|}
\hline Sample & Derivation of the second-degree & Final drying time
\end{tabular}

\begin{tabular}{||c|c|c|}
\hline $\mathrm{C}$ & $d w / d t=-0.0134-0.0004 \mathrm{t}$ & $\begin{array}{c}\text { (hour) } \\
\text { polynomial equations }\end{array}$ \\
\hline $\mathrm{A} 1$ & $d w / d t=-0.0271-0.0020 \mathrm{t}$ & 42 \\
\hline $\mathrm{A} 2$ & $d w / d t=-0.0419-0.0010 \mathrm{t}$ & 36 \\
\hline $\mathrm{K} 1$ & $d w / d t=-0.0389-0.0042 \mathrm{t}$ & 29 \\
\hline $\mathrm{K} 2$ & $d w / d t=-0.0665-0.0006 \mathrm{t}$ & 29 \\
\hline $\mathrm{K} 3$ & $d w / d t=-0.0683-0.0014 \mathrm{t}$ & 29 \\
\hline $\mathrm{D}$ & $d w / d t=-0.0546-0.0024 \mathrm{t}$ & 28 \\
\hline
\end{tabular}

\section{CONCLUSION}

Pre-treatment types strongly affect the drying time of plums. Chemical treatments with alkaline solution $(\mathrm{KOH})$ of the highest concentration $(1.5 \% \mathrm{v} / \mathrm{v})$ shorten the plum drying time. In the samples treated by abrasion, drying time was also shortened, thus indicating that the abrasion pre-treatment is highly efficient during plum drying. Mechanical pre-treatments in the drying process of plums have not been studied in great detail thus far so further studies are in order, focusing not just on the effect of mechanical pre-treatments on drying time but also on the nutritive quality of final products.

\section{REFERENCES}

Adiletta, G., Iannone, G., Russo, P., Patimo, G., De Pasquale, S., Di Matteo, M., (2014). Moisture migration by magnetic resonance imaging during eggplant drying: a preliminary study. International Journal of Food Science and Technology, 49, 2602-2609.

Adiletta, G., Senadeera, W., Liguori, L., Crescitelli, A., Albanese, D., Russo, P. (2015). The influence of abrasive pretreatment on hot air drying of grape. Food and Nutrition Sciences, 6, 355-364.

Adiletta, G.,Russo, P.,Senadeera, W., Matteo, M.Di (2016) Drying characteristics and quality of grape under physical pretreatment. Journal of Food Engineering, 172, 9-18

AOAC (1995). Official methods of analysis (16th ed.). Washington, DC: Association of Official Analytical Chemists.

Bursać Kovačević, D., Dragović Uzelac, V., Vujević, P., Obradović, D. (2014). Efect of dipping treatments on the quality of dried plums. Proceedings of 8th International Congress of Food Technologists, Biotechnologists and Nutritionists, Frece, Jadranka (ur.). Zagreb: Croatian Society of Food Technologists, Biotechnologists and Nutritionists, 285 $-290$.

Cinquanta, L., Di Matteo, M., Esti, M. (2002). Physical pretreatment of plums (Prunus domestica). Part 2. Effect on the quality characteristics of different prune cultivars. Food Chemistry 79, 233-238.

Cvejanov, S., Tošić, B., Gavrilović, M., Pejin, D., Grujić, O., Ružić, N. (2004). Prehrambena tehnologija, Zavod za udžbenike i nastavna sredstva, Beograd

Di Matteo, M., Cinquanta, L., Galiero, G., Crescitelli, S. (2000). Effect of a novel physical pretreatment process on the drying kinetics of seedless grapes. Journal of Food Engineering, 46, 83-89.

Di Matteo, M., Cinquanta, L., Galiero, G., Crescitelli, S. (2002). Physical pre-treatment of plums (Prunus domestica). Part 1. Modeling the kinetics of drying. Food Chemistry, 79, 227232.

Doymaz, I., Pala, M. (2002). The effects of dipping pretreatments on air-drying rates of the seedless grapes. Journal of Food Engineering, 52, 413-417.

Gazor, H.R., Maadani, S., Behmadi, H. (2014). Influence of air temperature and pretreatment solutions on drying time, energy consumption and organoleptic properties of sour cherry. Agriculturae conspectus scientificus, 79, 119-124.

Grabowski, S., Marcotte, M., Ramaswamy, H. (2005). Dehydrated Vegetables: Principles and Applications in Hui, Y. H., Sherkat, F. (ed.): Handbook of Food Science, Technology, and Engineering - 4 Volume. CRC Press.

Jazini, M.H. and Hatamipour M.S. (2010). A new physical pretreatment of plum for drying. Food and Bioproducts Processing, 88, 133-137.

Mitić, N.Č., Stojiljković, S.T., Stojiljković, D.T., Ranđelović, D.M., Todorović, B.Ž., Mitić N.Č. (2015). The influence of pretreatments on the convective drying of pumpkin pieces (Cucurbita maxima) at different air temperatures. Journal on Processing and Energy in Agriculture, 19, 5, 259-262

Okos M.R., Narsimham G., Singh R.K. and Witnauer A.C. (1992). Food dehydration. In: Heldman D.R. and Lund D.B. (eds), Handbook of Food Engineering. New York: Marcel Dekker.

Tarhan, S. (2007). Selection of chemical and thermal pretreatment combination for plum drying at low and moderate drying air temperatures. Journal of Food Engineering, 79, 255260.

United Nations (2003). UNECE STANDARD DDP-07 concerning the marketing and commercial quality control of PRUNES. United Nations Economic Commission for Europe, New York and Geneva.

Received: 08. 03. 2019.

Accepted: 20. 08. 2019. 